\title{
PERAN TEMAN SEPERMAINAN DALAM MEMBENTUK SIKAP PEMUDA PEDESAAN TERHADAP PEKERJAAN DI SEKTOR PERTANIAN PADI (Kasus Pemuda di Desa Ciasmara, Kecamatan Pamijahan Kabupaten Bogor)
}

\author{
Yogaprasta Adi Nugraha $\left.{ }^{1 *}\right)$ dan R. Atang Supriatna ${ }^{1)}$ \\ ${ }^{1}$ Faculty of Social Science and Humanities Pakuan University \\ ${ }^{*}$ Corresponding author : yogaprasta_adinugraha@yahoo.com
}

To cite this article:

Nugraha, Y., \& Supriatna, R. (2020). Peran Teman Sepermainan dalam Membentuk Sikap Pemuda Pedesaan terhadap Pekerjaan di Sektor Pertanian Padi (Kasus Pemuda di Desa Ciasmara, Kecamatan Pamijahan Kabupaten Bogor). JIA (Jurnal IImiah Agribisnis) : Jurnal Agribisnis dan IImu Sosial Ekonomi Pertanian, 5(1), 1 10. doi:http://dx.doi.org/10.37149/jia.v5i1.10625

Received: January 23, 2020; Accepted: February 11, 2020; Published: February 13, 2020

\section{ABSTRACT}

The agricultural sector is holding a pivotal position to national income but however, the importance of agricultural sector is not supported by the regeneration of agriculture workers. The number of agricultural workers continuously decreasing during time, in order to understand this phenomena there is a number of factors that have led to a decline in youth participation in agriculture sector, yet there is only limited research that is trying to determine the relationship between socialization agent and working preference. This study has several objectives, among others: (1) Identifying youth interactions with peer-group in the agricultural sector. (2) Identifying youth attitudes towards agriculture work (3) Analyzing the correlation between interactions with friends in the agricultural sector with youth attitudes towards agriculture work. This research uses quantitative method with a descriptive - correlational approach and was taken place in Ciasmara Village, Pamijahan District, Bogor Regency from March 2019 until Juli 2019. A total of 129 youth were selected as research respondents in this study. This study found that parents and peers have important positions in making youth interested in working in the agricultural sector. The two primary socialization agents were able to influence youth with different approaches. Parents through workinvolvement as family labor meanwhile, the peer-groups through doing activities together in farmland.

Keywords: attitude towards agriculture sector; parents, peer-group; socialization agent

\section{PENDAHULUAN}

Secara historis, Indonesia dikenal sebagai Negara agraris hal tersebut semakin didukung oleh pencapaian Indonesia untuk berswasembada beras pada tahun 1984. Sekalipun saat ini Indonesia cenderung tidak swasembada beras, namun urgensi sektor pertanian di Indonesia masih bisa terlihat dari kontribusi sektor pertanian terhadap perekonomian Indonesia. Menurut (Badan Pusat Statistik, 2017), sektor pertanian memiliki kontribusi kedua terbesar, setelah sektor industri pengolahan, terhadap Produk Domestik Bruto (PDB). Urgensi sektor pertanian di Indonesia tidak hanya sebatas kontribusinya terhadap Produk Domestik Bruto (PDB) tetapi juga terhadap terhadap penyediaan pangan nasional di Indonesia mengingat jumlah penduduk Indonesia terus meningkat dari tahun ke tahun, bahkan saat ini penduduk Indonesia telah mencapai 265 Juta. Namun, yang tengah menjadi paradoks di sektor pertanian adalah posisi penting pertanian dalam PDB dan penyediaan pangan nasional tidak serta merta didukung oleh regenerasi pekerja muda di sektor pertanian (Nugraha \& Herawati, 2015). Fenomena ketidaktertarikan pemuda bekerja di sektor pertanian disebabkan beberapa hal antara lain: (1) Tingginya peralihan lahan sawah menjadi lahan yang penggunaannya bukan untuk sawah atau pertanian sehingga aksesibilitas petani baik tua dan muda terhadap tanah menjadi sangat terbatas. (2) Secara ekonomi, pemuda menganggap sektor pertanian kurang menguntungkan, meskipun tidak selalu demikian. (3) Sistem sosial sekitar pemuda yang cenderung menkonstruksi nilai pertanian secara negatif. (4) Pertanian dianggap tidak bergengsi oleh pemuda di desa (Nugraha (2012); Nugraha \& Herawati, (2015); (Valdiani et al., 2017); (White, 
2018). Dalam rangka memahami preferensi pemuda desa untuk bekerja baik di sektor pertanian maupun sektor non pertanian maka perlu memahami sistem sosial terdekat mereka.

Nugraha (2012) menemukan bahwa sistem sosial terdekat seperti orang tua, teman, dan media massa mampu membangun ketertarikan/ketidaktertarikan pemuda untuk bekerja di sektor pertanian hortikultura. Demikian pula studi yang dilakukan oleh Valdiani et al., (2017) yang berhasil memberikan perspektif baru bahwasannya orang tua dan media massa memiliki peranan penting dalam menkonstruksi nilai pertanian. Penelitian kali ini memiliki perbedaan mendasar dengan penelitian sebelumnya yang telah dilakukan oleh Nugraha (2012) dan Valdiani et al., (2017) perbedaan mendasarnya adalah sektor pertanian yang akan dikaji saat ini adalah pertanian padi dan pemuda yang menjadi obyek penelitian adalah pemuda yang masih bersekolah tingkat SLTP - SLTA. Tanpa mengurangi urgensi subsistem penelitian lainnya, penelitian ini mencoba fokus lebih mendalam terhadap subsistem sosial teman sepermainan (peer grup) karena ketika memasuki usia remaja, teman sepermainan menjadi subsistem sosial yang paling dekat remaja. Menurut Nugraha (2012), pemuda lebih terpengaruh oleh teman sepermainan mereka, pemikiran tersebut muncul karena terinspirasi oleh pengaruh sosial (social influence). Terdapat 2 (dua) peubah besar yang dapat menggambarkan besarnya pengaruh teman sepermainan terhadap seorang remaja, peubah pertama adalah peubah yang berhubungan dengan kedekatan (closeness) hubungan dengan teman, yang kedua adalah besarnya lingkungan sosial (social network). Pada dasarnya seorang teman dapat memberikan pengaruh yang kuat pada individu jika beberapa hal terpenuhi, yaitu: (1) waktu yang dihabiskan bersama-sama dengan teman (2) memiliki hubungan pertemanan yang saling menguntungkan (3) memiliki kesamaan dalam kegiatan yang berisiko sebelumnya (4) jaringan pertemanan yang kecil dan (5) hubungan yang tidak baik dengan keluarga.

Pewarisan nilai pertanian dari sistem agen sosialisasi primer kepada pemuda desa terjadi dalam kehidupan sehari - hari. Berdasarkan isu yang telah dijabarkan di atas, maka riset ini akan dirumuskan dengan mencoba menjawab beberapa pertanyaan penelitian, antara lain adalah: (1) Bagaimana tingkat interaksi pemuda desa dengan teman di sektor Pertanian Padi di Desa Ciasmara, Kecamatan Pamijahan, Kabupaten Bogor? (2) Bagaimana sikap pemuda desa di Desa Ciasmara, Kecamatan Pamijahan terhadap pekerjaan di sektor pertanian? (3) Bagaimana hubungan antara interaksi pemuda desa dengan teman di bidang pertanian dengan sikap pemuda desa terhadap pekerjaan di sektor Pertanian?. Berangkat dari pertanyaan penelitian yang telah dijelaskan di atas, maka tujuan dari penelitian ini adalah (1) Mengidentifikasi interaksi pemuda dengan teman di sektor pertanian di Desa Ciasmara, Kecamatan Pamijahan, Kabupaten Bogor. (2) Mengidentifikasi sikap pemuda desa terhadap pekerjaan di sektor pertanian padi (3) Menganalisis hubungan antara interaksi teman di sektor pertanian dengan sikap pemuda desa terhadap pekerjaan di bidang Pertanian padi. Penelitian ini diharapkan dapat berkontribusi terhadap debat akademik mengenai fenomena migrasi pemuda dari dalam desa ke luar desa. Hasil penelitian ini diharapkan juga mampu menjadi jembatan rasional yang menjelaskan motif sosiologis pemuda untuk bermigrasi keluar dari desa dan bekerja di sektor pertanian.

\section{MATERI DAN METODE}

Desa Ciasmara dipilih sebagai lokasi penelitian dengan berbagai pertimbangan, antara lain adalah (1) Desa tersebut merupakan lumbung padi Kabupaten Bogor, (2) Desa tersebut masih melestarikan tradisi sedekah bumi, (3) Desa tersebut terletak di dekat pusat Industri garmen/tekstil di wilayah Kabupaten Bogor yang terletak di bagian barat (Nugraha \& Nugroho, 2019). Lokasinya yang berdekatan dengan Industri garmen/tekstil membuat banyak pemuda di Desa Ciasmara bekerja keluar sektor pertanian (Nugraha dan Nugroho, 2018), sehingga faktor penarik (Pull - Factor) dari luar desa dapat mempengaruhi ketertarikan atau ketidaktertarikan pemuda untuk bekerja di sektor pertanian di Desa Ciasmara. Penelitian ini dilaksanakan sejak Februari 2019 sampai dengan Juli 2019. Sementara itu populasi dalam penelitian ini adalah pemuda (baik perempuan dan laki-laki) pemuda desa yang berada pada rentang usia 15 - 24 tahun dan berasal dari orang tua petani. Teknik penarikan sampling dalam penelitian adalah purposive sampling, sehingga berdasarkan hasil sampling dengan metode (Neuman, 2014) sebanyak 129 pemuda di Desa Ciasmara terpilih sebagai sampel penelitian. Penelitian ini menggunakan beberapa teknik analisis data, antara lain adalah teknik analsisi deskriptif dan teknik analisis inferensia. Dalam penelitian ini teknik analisis deskriptif digunakan untuk memberikan gambaran frekuensi, persentase dan rataan skor dari beberapa variabel antara lain karakteristik pemuda desa, interaksi pemuda dengan teman sepermainan dan sikap pemuda desa terhadap pekerjaan di sektor pertanian padi. Sementara teknik analisis inferensia yang digunakan dalam penelitian ini adalah uji korelasi rank spearman untuk melihat hubungan antara dua variabel yang bersifat ordinal, antara lain interaksi pemuda dengan teman sepermainan 
dan sikap pemuda desa terhadap pekerjaan di sektor pertanian padi.

Penelitian ini dibangun berdasarkan model ekologi manusia milik Brofenbrenner dan fokus pada sistem sosial terdekat pemuda yaitu teman sepermainan (peer-group) dalam membentuk sikap pemuda (Walgito, 2010). Model ini menjelaskan bahwa perilaku individu akan sangat dipengaruhi oleh sistem - sistem utama yang berada di sekitar individu tersebut. Secara teoritis terdapat 3 aktor sosialisasi utama yang mampu membentuk sikap dan perilaku individu antara lain orang tua, teman, media massa. Dalam memahami sejauhmana teman sepermainan mampu mempengaruhi pembentukan sikap pemuda terhadap pekerjaan di sektor pertanian, maka penelitian akan melihat interaksi remaja dengan teman sepermainan di sektor pertanian. Namun dalam memahami sikap pemuda terhadap pekerjaan di bidang pertanian maka perlu juga untuk melihat konteks pemuda tersebut, dalam riset ini konteks pemuda tersebut dimaksud dengan karakteristik pemuda. Sehingga konstruksi variabel dalam penelitian ini adalah karakteristik pemuda (X1), interaksi dengan teman sepermainan di sektor pertanian (X2) dan Sikap pemuda desa terhadap pekerjaan di sektor pertanian padi (Y1). Terdapat dua hipotesis dalam penelitian ini, antara lain adalah: (1) Karakteristik pemuda desa di duga memiliki hubungan signifikan kuat dan nyata terhadap sikap pemuda desa terhadap sektor pertanian dan (2) Interaksi antara pemuda desa dengan teman sepermainan di duga memiliki hubungan signifikan dan nyata terhadap sikap pemuda desa.

\section{HASIL DAN PEMBAHASAN}

\section{Konteks Desa Penelitian}

Desa Ciasmara terletak di Kecamatan Pamijahan di Kabupaten Bogor wilayah barat. Desa ini berjarak sekitar 46 kilometer dari ibukota kabupaten Bogor, $147 \mathrm{Km}$ dari lbukota provinsi Jawa Barat, dan $79 \mathrm{Km}$ dari lbukota Indonesia. Berdasarkan hasil wawancara dengan Kepala Desa Ciasmara, diperoleh informasi bahwa Desa Ciasmara itu sendiri pada awalnya merupakan desa induk karena beberapa pertimbangan maka pada tahun 1978 Desa Ciasmara mekar menjadi tiga desa antara lain adalah Desa Ciasmara, Desa Ciasihan dan Desa Cibunian. Secara geografis, wilayah utara Desa Ciasmara berbatasan dengan Desa Ciasihan, sementara itu wilayah bagian barat berbatasan dengan Desa Cibunian, dan bagian selatan berbatasan dengan Desa Purwabakti. Desa Ciasmara terletak kurang lebih $20 \mathrm{~km}$ dari jalan provinsi utama atau sekitar $25 \mathrm{~km}$ dari Kampus IPB-University Dramaga atau sekitar $40 \mathrm{~km}$ dari pusat Kota Bogor. Desa Ciasmara merupakan salah satu lumbung Padi di Kabupaten Bogor (Nugraha \& Nugroho, 2019). Berdasarkan hasil wawancara dengan seseupuh desa Ciasmara, Abah Odo (90), nama Desa Ciasmara muncul dari sejarah panjang hubungan antara pemuda dan pemudi di wilayah tersebut. Secara etimologi, Ciasmara berasal dari kata Ci dan Asmara atau air yang membawa kasih sayang.Menurut hasil wawancara dengan sekretaris Desa Ciasmara, 80 persen penduduk Desa Ciasmara bekerja sebagai petani. Terdapat dua wilayah pertanian utama di Desa Ciasmara, yaitu di daerah Kebon Alas dan Jogjogan llir.

Tabel 1. Karakteristik pemuda Desa Ciasmara

\begin{tabular}{lcc}
\hline \multicolumn{1}{c}{ Karakteristik Responden } & Frekuensi (Org) & Persentase (\%) \\
\hline Usia & & \\
15 (Remaja Pertengahan) & 49 & 37.98 \\
16-18 (Remaja Akhir) & 76 & 58.91 \\
19-24 (Dewasa Awal) & 4 & 3.10 \\
\hline Jenis Kelamin & & \\
$\quad$ Laki - Laki & 60 & 46.51 \\
$\quad$ Perempuan & 69 & 53.49 \\
\hline Tingkat Pendidikan & & \\
$\quad$ SLTP & 76 & 58.92 \\
SLTA & 50 & 38.76 \\
$\quad$ Lulus SLTA & 3 & 2.32 \\
\hline Kepemilikan Lahan & & \\
Ya & 65 & 50.39 \\
$\quad$ Tidak & 64 & 49.61 \\
\hline
\end{tabular}

\section{Usia}

Dalam penelitian ini, usia didefinisikan sebagai lama hidupnya pemuda di Desa Ciasmara dari mulai dilahirkan sampai dengan penelitian ini dilakukan, sementara itu secara operasional penelitian ini melihat usia sebagai lama hidup pemuda di Desa Ciasmara sampai dengan penelitian ini dilakukan. Menurut Nugraha (2012), responden pada penelitian ini dibagi berdasarkan tingkatan 
perkembangan psikologis. Dari Tabel di atas dapat dilihat bahwa usia pemuda Desa Ciasmara terkategorikan remaja akhir atau berada dalam kelompok usia 16 - 18 tahun, kemudian pada posisi kedua diikuti oleh pemuda desa yang terkategorikan remaja pertengahan, dan terakhir adalah pemuda desa yang terkategorikan usia dewasa awal atau berada dalam kategori usia $19-24$ tahun. Tingginya jumlah remaja berusia 16 - 18 tahun karena menurut penuturan dari Kepala Desa dan Sekretaris Desa, remaja pada selang usia tersebut masih duduk dibangku SLTA dan belum bermigrasi keluar desa. Sementara itu, kategori usia 19-24 tahun, pemuda yang berasal dari keluarga prasejahtera cenderung sedikit jumlahnya karena banyak yang keluar desa untuk bekerja sebagai tukang sate pikul, tukang bangunan, dan tukang bubur. Sementara itu, untuk pemuda yang berasal dari keluarga kelas menengah dan atas cenderung untuk menyekolahkan anak mereka keluar seperti kuliah di UIKA, Sekolah Tinggi Penyuluhan Pertanian, dan Sekolah Tinggi llmu Agama yang berada di Cibungbulang. Temuan ini sejalan dengan beberapa penelitian sebelumnya yang memang menjelaskan pemuda desa cenderung bermigrasi dahulu keluar desa ketika baru lulus SLTA, mereka memilih untuk mencari pengalaman terlebih dahulu keluar kota baru ketika akan menikah atau ketika tidak mendapatkan pekerjaan lagi di kota (White, 2018); (Nugraha \& Herawati, 2015).

\section{Jenis Kelamin}

Dalam penelitian ini, jenis kelamin di definisikan sebagai kondisi biologis pemuda di Desa Ciasmara saat penelitian ini dilakukan. Tabel 2 menunjukan bahwa terdapat sekitar 53,49 persen responden penelitian berjenis kelamin perempuan dan juga terdapat 46.51 persen responden penelitian adalah laki - laki. Temuan ini menunjukan bahwa perempuan muda memiliki proporsi yang lebih tinggi dibandingkan dengan laki - laki Hal ini sejalan dengan data populasi jumlah penduduk di Desa Ciasmara yang menunjukan bahwa jumlah populasi perempuan lebih tinggi dari pada laki - laki. Secara empirik temuan tersebut juga didukung oleh hasil wawancara dengan warga desa Ciasmara yang bernama Wahyudi (30), dia mengatakan bahwa kebanyakan pemuda desa setelah lulus SMA mencoba dulu kerja keluar desa, jenis pekerjaan pemuda pun beragam ada yang berjualan sate pikul, kerja di pabrik, jualan di pasar, dan menjadi sekuriti (satpam) di Jakarta. Namun, Wahyudi juga mengatakan bahwa biasanya pemuda akan kembali lagi ke desa jika mau menikah, usahanya tidak bagus di kota, atau ada keluarga yang sakit sehingga pemuda harus bantu mengurus orangtua mereka yang sakit. Secara sosiologis, jumlah perempuan yang menetap di Desa Ciasmara lebih banyak dibandingkan jumlah laki-laki hal itu dikarenakan laki - laki di Desa Ciasmara memiliki kecenderungan untuk bermigrasi terlebih dahulu sebelum kembali lagi ke desa. Temuan ini didukung oleh riset yang dilakukan oleh (Jayawinangun \& Nugraha, 2018) bahwa pemuda di Desa Ciasmara keluar desa untuk mencari pengalaman pekerjaan terlebih dahulu baru kemudian kembali lagi ke desa untuk menikah dan tinggal di dalam desa.

\section{Tingkat Pendidikan}

Pada penelitian ini, tingkat pendidikan didefinisikan sebagai pendidikan formal terakhir yang tengah dijalani oleh pemuda di Desa Ciasmara sampai pada saat penelitian ini dilakukan. Pada penelitian ini terdapat tiga kelompok tingkat pendidikan, terdapat remaja yang masih duduk di bangku SLTP, SLTA, dan yang sudah Lulus SLTA. Dari penelitian ini ditemukan bahwa terdapat sekitar 58.92 persen pemuda yang duduk di bangku SLTP, 28.76 persen remaja yang duduk di bangku SLTA dan sekitar 2.32 persen yang sudah lulus SLTA tetapi tidak melanjutkan. Berdasarkan informasi dari Sekretaris Desa, untuk generasi muda Desa Ciasmara tingkat pendidikannya sudah relatif membaik dibandingkan generasi sebelumnya. Sekretaris Desa juga menjelaskan, Desa Ciasmara baru tahun 2005 memiliki sekolah setara SLTA, sebelumnya fasilitas pendidikan tertinggi di Desa Ciasmara hanya SLTP atau setara, dan SLTA terdekat pada saat itu adalah SLTA Taman Siswa yang terletak di Desa Situ Udik atau sekitar $15 \mathrm{~km}$ dari Desa Ciasmara, hal ini diakui oleh Sekretaris Desa sangat memberatkan karena biaya transportasi dari Desa Ciasmara menuju Desa Situ Udik dianggap mahal oleh masyarakat di Desa Ciasmara. Terbatasnya aksesibilitas pendidikan SLTA menjadikan dulu mayoritas pendidikan masyarakat Desa Ciasmara hanya SLTP. Namun sejak beberapa tahun ini, kondisi pendidikan di Desa Ciasmara mulai berubah, hal ini karena SLTA sudah masuk ke Desa Ciasmara, yaitu SMK Bumi Putera dan SMA Muhammadiyah Pamijahan. Hal ini berdampak terhadap banyaknya remaja di Desa Ciasmara yang pada awalnya berencana untuk langsung bekerja tetapi menunda niatnya terlebih dahulu untuk kemudian meneruskan sekolah di SLTA di Desa Ciasmara. Penelitian ini didukung oleh temuan dalam riset yang mengatakan bahwa bahwa aksesibilitas pendidikan saat ini sangat berbeda dengan satu dekade yang lalu dimana saat ini sekolah setingkat SLTA telah banyak ditemui di desa (Nugraha \& Nugroho, 2019). 


\section{Kepemilikan Lahan}

Pada penelitian ini, kepemilikan lahan didefinisikan sebagai status kepemilikan sawah orang tua dari responden penelitian. Pada penelitian ini status kepemilkan tanah hanya dibatasi kepada memiliki dan tidak memiliki (Nugraha, 2012). Berdasarkan kepemilikan lahan tani orangtua responden terbagi menjadi dua kelompok yaitu orang tua yang memiliki lahan pertanian sendiri dan orang tua yang tidak memiliki lahan pertanian sendiri. Terdapat 50.39 persen orang tua responden yang memiliki lahan pertanian dan 49.61 persen orang tua responden yang tidak memiliki lahan pertanian. Temuan ini sejalan dengan apa yang ditemukan di lapang bahwa proporsi kepemilikan lahan pertanian di Desa Ciasmara cenderung imbang baik petani yang memiliki lahan pertanian maupun petani yang tidak memiliki lahan pertanian (penggarap). Petani penggarap di Desa Ciasmara menggarap sawah yang juga dimiliki oleh petani di Desa Ciasmara. Berbeda dengan konteks Cianjur atau Karawang dimana sawah banyak dimiliki oleh orang yang berada di luar wilayah mereka, di Desa Ciasmara kepemilikan lahan banyak dimiliki oleh orang yang berada di dalam desa sehingga aliran keuangan dari hasil pertanian tetap berada di dalam desa. Menurut (Harahap \& Ambarwati, 2015), tanah memegang peranan penting dalam menentukan tingkat partisipasi pemuda dalam kegiatan pertanian. Dalam konteks Jawa, penguasaan lahan petani hanya sekitar $0.25 \mathrm{Ha}$ sementara itu petani luar jawa penguasaan lahan dapat berkisar $0.5-1 \mathrm{Ha}$.

\section{Interaksi dengan Teman}

Pada penelitian ini, interaksi dengan teman didefinisikan sebagai keterlibatan orang muda bersama teman - temannya dalam berinteraksi di wilayah pertanian dan bersama teman bekerja di sektor pertanian.

Tabel 2. Sebaran responden berdasarkan kegiatan bertani bersama teman.

\begin{tabular}{lccc}
$\begin{array}{c}\text { Parameter } \\
\text { Jawaban }\end{array}$ & $\begin{array}{c}\text { Frekuensi } \\
\text { (Orang) }\end{array}$ & $\begin{array}{c}\text { Persen } \\
(\%)\end{array}$ & $\begin{array}{c}\text { Rataan } \\
\text { Skor }\end{array}$ \\
\hline Bertani Bersama Teman & 33 & 25.58 & \\
$\quad$ Tidak Pernah & 54 & 41.86 & 2.23 \\
Jarang & 40 & 31.01 & \\
$\quad$ Cukup Sering & 2 & 1.55 & \\
$\quad$ Sering & 0 & 0.00 & \\
Bermain di Sawah Bersama Teman & 26 & 20.16 & \\
$\quad$ Tidak Tahu & 96 & 74.42 & \\
Kurang Tahu & 7 & 5.43 & \\
Tahu & & & \\
$\quad$ Sangat Tahu & 2.51: Jarang; 2.52 - 3.27: Cukup Sering; 3.28 - 4: Sering.
\end{tabular}

Penelitian ini menemukan bahwa sebagian besar pemuda di Desa Ciasmara jarang dan tidak pernah terlibat bertani bersama teman mereka. Seperti yang dapat dilihat pada tabel di atas sekitar 41.86 persen pemuda jarang bertani bersama teman mereka, dan sebanyak 25.58 persen pemuda bahkan tidak pernah bertani bersama temannya di sawah. Jika dilihat nilai rataan skor, nilai 2.23 menunjukan bahwa pemuda di Desa Ciasmara cenderung jarang untuk bertani bersama temannya di sawah. Rendahnya interaksi pemuda bersama teman sepermainannya dalam kegiatan bertani bersama temannya disebabkan karena pemuda di Desa Ciasmara masih aktif mengikuti kegiatan belajar dan mengajar di sekolah mereka. Padatnya jadwal sekolah pemuda membuat mereka tidak dapat ikut bertani, kecuali pada tahapan tertentu seperti tahapan panen. Rendahnya interaksi pemuda dalam bertani bersama teman juga disebabkan pemuda belum memiliki kuasa penuh untuk mengelola sawah, hal ini juga ditemukan dalam riset yang dilakukan oleh (Valdiani et al., 2017) ; Nugraha (2012); dan (Nugraha \& Herawati, 2015) pemuda baru dapat mengelola sawah pertanian mereka secara mandiri atau memiliki kuasa penuh ketika mereka sudah menikah atau saat orang tua mereka sudah meninggal. Fenomena terbatasnya aksesibilitas pemuda untuk dapat memperoleh lahan pertanian menjadi salah satu alasan pemuda belum mau bertani saat mereka muda (White, 2018)

Penelitian ini juga melihat kegiatan bermain bersama teman di sawah sebagai salah satu indikator penting untuk menggambarkan interaksi bersama teman, konsep kedekatan (proximity) merupakan hal penting yang dapat mempengaruhi konstruksi nilai pertanian di kalangan remaja di Desa Ciasmara. Pada penelitian ini, pemuda di Desa Ciasmara cukup sering bermain di sawah bersama teman, hal ini dapat dilihat dari rataan skor, 2.84 yang mengindikasikan bahwa pemuda di 
Desa Ciasmara cukup sering bermain bersama teman - teman mereka di sawah. Hal ini terkonfirmasi dari hasil wawancara dengan pemuda di Desa Ciasmara. Mereka cenderung sering bermain di sawah bersama teman - teman mereka terutama ketika masa panen telah selesai, pemuda sering bermain bola atau bermain layangan di sawah yang telah di panen. Selain itu, pemuda juga sering bermain di saluran irigrasi sekunder baik untuk berenang atau sekedar memancing ikan. Nugraha (2012) dalam risetnya menemukan bahwa interaksi dengan teman sepermainan di bidang pertanian mampu membuat pemuda mengenal pertanian sejak dini baik secara mengenai pengetahuan teknis pertanian, pengetahuan yang berkaitan dengan sistem pertanian dari hulu - hilir. (Nugraha \& Nugroho, 2019) menjelaskan bahwa teman sepermainan merupakan salah satu kelompok kerangka acuan yang dapat mempengaruhi pemuda dalam melihat pekerjaan. Walgito (2010) juga menjelaskan bahwa keterlibatan pemuda dalam bermain atau bekerja bersama teman secara terus menerus dapat membentuk nilai baru tentang nilai pekerjaan.

\section{Sikap Pemuda terhadap Pekerjaan di Sektor Pertanian}

Pada penelitian ini, sikap didefinisikan sebagai kecenderungan bertindak pemuda Desa Ciasmara dalam memilih pertanian sebagai pekerjaan. Dalam memahami sikap pemuda Desa Ciasmara terhadap pekerjaan di sektor pertanian padi, perlu dilihat secara lebih detail indikator indikator yang mampu membentuk sikap seperti kognitif, afektif, konatif (Walgito 2010).

Tabel 3. Sebaran responden berdasarkan aspek sikap

\begin{tabular}{|c|c|c|c|}
\hline $\begin{array}{l}\text { Indikator } \\
\text { Sikap }\end{array}$ & $\begin{array}{l}\text { Frekuensi } \\
\text { (Orang) }\end{array}$ & $\begin{array}{l}\text { Persen } \\
(\%)\end{array}$ & $\begin{array}{l}\text { Rataan } \\
\text { Skor }\end{array}$ \\
\hline \multicolumn{4}{|l|}{ Kognitif } \\
\hline Tidak Tahu & 0 & 0.00 & \multirow{4}{*}{2.76} \\
\hline Kurang Tahu & 26 & 20.16 & \\
\hline Tahu & 96 & 74.42 & \\
\hline Sangat Tahu & 7 & 5.43 & \\
\hline \multicolumn{4}{|l|}{ Afeksi } \\
\hline Tidak Baik & 4 & 3.10 & \multirow{4}{*}{2.61} \\
\hline Kurang Baik & 48 & 37.21 & \\
\hline Cukup Baik & 67 & 51.94 & \\
\hline Baik & 10 & 7.75 & \\
\hline \multicolumn{4}{|l|}{ Psikomotorik } \\
\hline Tidak Tertarik & 31 & 24.03 & \multirow{4}{*}{2.21} \\
\hline Kurang Tertarik & 55 & 42.64 & \\
\hline Tertarik & 38 & 29.46 & \\
\hline Sangat Tertarik & 5 & 3.88 & \\
\hline
\end{tabular}

\section{Aspek Koginitif, Afektif, dan Psikomotorik}

Indikator kognitif yang dimaksud dalam penelitian ini adalah pengetahuan pemuda desa terhadap pengetahuan teknis pertanian mulai dari tahapan pengolahan tanah, pembibitan, penanaman, penyiangan, pemberian pestisida, panen, dan paska panen. Dari Tabel 9 di atas diperoleh informasi bahwa pemuda di Desa Ciasmara memiliki pengetahuan tentang bertani padi, hal tersebut dapat dilihat dari nilai rataan skor 2.76 yang terkategorikan tahu. Pengetahuan pemuda terkait teknik pertanian padi sebagian besar di peroleh dari orang tua mereka ketika pemuda dilibatkan dalam kegiatan pertanian. Informasi pertanian yang paling banyak diketahui oleh pemuda desa adalah pengetahuan mengenai pengolahan lahan dan pengetahuan mengenai panen, sementara itu pengetahuan yang paling rendah adalah pengetahuan mengenai pupuk.

Sementara itu untuk aspek afeksi pada penelitian ini dilihat sebagai evaluasi pemuda terhadap pekerjaan di sektor pertanian padi. Secara afeksi, pemuda di Desa Ciasmara masih memilih menilai cukup baik pekerjaan di sektor pertanian padi di Desa Ciasmara. Hal ini terlihat dari nilai rataan skor sebesar 2.61, yang terkategorikan setuju bahwa pekerjaan di sektor pertanian padi masih cukup baik dan memiliki nilai positif di mata remaja. Pemuda di Desa Ciasmara masih melihat pertanian sebagai hal positif dan menarik karena sebagian besar orang dewasa di Ciasmara bekerja sebagai petani padi hal itu terkonfirmasi dari pernyataan Kepala Desa Ciasmara yang mengatakan 80 persen penduduk usia bekerja di Ciasmara bekerja di sektor pertanian padi baik sebagai petani pemilik, petani penggarap, dan buruh tani. Desa Ciasmara merupakan salah satu lumbung padi di Kabupaten Bogor dan telah memiliki beras dengan merek lokal. Afeksi yang positif ini dikarenakan 
pemuda di Desa Ciasmara masih sering dilibatkan oleh orang tua mereka dalam kegiatan panen, sehingga hal tersebut memberikan gambaran mengenai pertanian. Selain itu juga karena praktik pertanian di beberapa wilayah dalam desa tersebut masih menerapkan pertanian yang masih menjunjung tinggi tradisi budaya lokal seperti sedekah bumi dan praktik pertanian ramah lingkungan, hal tersebut dapat mempengaruhi bagaimana masyarakat melihat pertanian, hal ini sejalan apa yang diutarakan diutarakan oleh (Ashari et al., 2016)

Indikator Psikomotorik dalam penelitian ini didefinisikan sebagai ketertarikan pemuda Desa Ciasmara untuk bekerja menjadi petani padi. Tabel 11 menunjukan bahwa pemuda Ciasmara kurang tertarik untuk bekerja menjadi petani. Hal ini dijelaskan oleh ketua Gapoktan Asmara Jaya Pak Maji (50), dirinya mengatakan bahwa pemuda biasanya tidak langsung tertarik untuk langsung bekerja di sektor pertanian padi. Pada umumnya pemuda di Desa Ciasmara memilih untuk bekerja dulu di luar sektor pertanian baru setelah menikah, memperoleh kuasa penuh dari orang tuanya untuk mengelola sawah, atau orang tua mereka telah sakit - sakitan mereka kembali lagi ke Desa Ciasmara. Berdasarkan penuturan Pak Agah (51), rata - rata petani tua di Desa Ciasmara, ketika muda mereka pasti bekerja di sektor non-pertanian dulu baru ketika mereka merasa lelah, menikah atau usahanya tidak berhasil mereka akan kembali lagi ke desa. Hal ini sejalan dengan temuan Valdiani et al., (2017), White, (2018); Nugraha \& Herawati, (2015) yang menyatakan keputusan migrasi pemuda di sektor pertanian bukan keputusan sekali dalam seumur hidup dan mengalami perubahan sesuai kondisi di dalam desa dan di luar desa itu sendiri. Penelitian ini menemukan bahwa terdapat beberapa alasan kenapa pemuda di Desa Ciasmara tidak tertarik untuk bekerja di sektor pertanian. (1) Tidak memiliki akses langsung untuk bertani. Bagi pemuda yang orang tua mereka memiliki sawah, anak mereka tidak serta-merta dapat langsung memperoleh kewenangan untuk mengakses sawah tersebut. Pada umumnya pemuda baru mendapatkan akses penuh terhadap sawah ketika orangtua mereka sudah merasa cukup lelah untuk bertani, atau ketika pemuda tersebut sudah menikah. (2) Bagi pemuda yang orang tua mereka tidak memiliki sawah, mereka cenderung memilih untuk pergi keluar desa terlebih dahulu untuk mencari pekerjaan diluar desa. Baru setelah mereka sudah merasa lelah bekerja atau ketika usaha mereka di luar desa tidak begitu berhasil maka mereka akan kembali kembali ke sawah.

\section{Hubungan Antara Karakteristik Pemuda Desa dengan Sikap Terhadap Pekerjaan di Sektor Pertanian}

Karakteristik individu pemuda desa merupakan ciri - ciri khusus yang melekat pada pemuda desa dan menjadi pembeda antara satu pemuda dengan pemuda yang lainnya. Pada penelitian ini terdapat empat karakteristik individu pemuda, yaitu usia pemuda, tingkat pendidikan pemuda, kepemilikan lahan orang tua, dan jenis kelamin.

Tabel 4. Hubungan antara karakteristik pemuda desa dengan sikap pemuda terhadap pekerjaan di sektor pertanian.

\begin{tabular}{lcc}
\multicolumn{1}{c}{$\begin{array}{c}\text { Karakteristik Pemuda Desa } \\
(\mathrm{X} 1)\end{array}$} & Analisis Data & $\begin{array}{c}\text { Sikap } \\
(\mathrm{Y} 1)\end{array}$ \\
\hline Usia & $R s$ & $-0.175^{*}$ \\
\hline Tingkat Pendidikan & $R s$ & 0.041 \\
\hline Kepemilikan Lahan & $R s$ & 0.020 \\
\hline Jenis Kelamin & $C c$ & 0.681 \\
\hline
\end{tabular}

Tabel di atas terlihat bahwa hanya satu karakteristik individu pemuda yang memiliki hubungan dengan sikap pemuda, yaitu Usia Pemuda, dengan nilai $\mathbf{- 0 . 1 7 5}$. Nilai negatif menunjukan bahwa semakin muda seseorang maka dia semakin sikapnya semakin positif atau pun sebaliknya semakin seorang pemuda mendekati usia dewasa dirinya semakin tidak tertarik untuk bekerja di sektor pertanian. Hal ini terjadi karena semakin usia seorang pemuda mendekati dewasa mereka akan mencari pekerjaan yang aksesnya relatif logis untuk mereka. Pertanian padi di Desa Ciasmara relatif tidak dapat diakses langsung oleh pemuda desa, biasanya mereka baru dipercaya untuk mengelola sawahnya langsung ketika sudah menikah atau ketika orang tua mereka sudah meninggal seperti yang diutarakan oleh (White, 2018); (Nugraha \& Herawati, 2015) bahwa akses lahan pertanian pada umumnya baru diberikan ketika orang tua sudah meninggal atau merasa terlalu tua untuk mengolah lahan pertanian. Sementara itu sebagian besar karakteristik individu pemuda di Desa Ciasmara tidak memiliki hubungan dengan sikap pemuda terhadap pekerjaan di sektor pertanian artinya variasi variabel tingkat pendidikan, kepemilikan lahan, dan jenis kelamin tidak memberikan perbedaan terhadap sikap pekerjaan di sektor pertanian padi. 


\section{Hubungan Antara Interaksi dengan Teman Sepermainan dengan Sikap Pemuda terhadap Pekerjaan di Sektor Pertanian Padi}

Tabel 13 menunjukkan interaksi pemuda bersama teman sepermainan di sektor pertanian memiliki hubungan dengan sikap pemuda terhadap pekerjaan di sektor pertanian padi. Untuk Indikator bekerja di sawah bersama teman memiliki nilai hubungan kuat dan sangat nyata 0.554 . Hal ini mengindikasikan bekerja di sawah bersama teman memiliki hubungan positif dengan sikap, artinya semakin sering pemuda bekerja bersama temannya di sawah maka akan semakin membuat sikap pemuda positif terhadap pekerja di sektor pertanian padi. Sementara itu indikator bermain bersama teman di sawah juga memiliki hubungan yang cukup kuat, sangat nyata, dan arah hubungan yang positif. Hal ini berarti semakin pemuda sering bermain bersama teman di sawah maka semakin positif sikap pemuda terhadap pekerja terhadap pertanian di sektor pertanian padi. Teman merupakan salah satu aktor sosialisasi primer bagi pemuda. Berbeda dengan orang tua yang menanamkan nilai melalui relasi kuasa dalam rumah tangga dan terdapat proses penanaman nilai yang cenderung melalui proses "paksaan", teman sepermainan menanamkan nilai melalui proses interaksi yang cenderung setara dan tidak ada paksaan. Relasi pertemanan pada umumnya terbentuk melalui proses shared-value sehingga memiliki kecenderungan bertahan yang lama. Menurut Nugraha (2012), pemuda yang memiliki tingkat kedekatan yang tinggi dengan teman di bidang pertanian artinya pemuda tersebut teman-teman dekatnya memiliki kegiatan di bidang pertanian, sehingga dalam pembicaraannya pun mereka lebih sering berdiskusi dan membicarakan mengenai pertanian, sehingga dapat menggambarkan tingkah laku yang hampir sama, dan memiliki perasaan yang sama dengan suatu obyek. Demikian juga dengan apa yang diutarakan oleh Walgito (2010) bahwa teman sepermainan merupakan aktor sosialisasi primer yang dapat membentuk preferensi pemuda terhadap suatu bidang pekerjaan. Hal ini menjadi logis, pemuda yang memiliki kedekatan dengan teman sepermainan di sektor pertanian akan cenderung lebih sering menerima nilai - nilai positif tentang pertanian, sekalipun terdapat nilai negatif pertanian maka para pemuda tidak terlalu khawatir karena sistem terdekatnya mampu nilai - nilai negatif tersebut tidak muncul.

Tabel 5. Hubungan antara interaksi dengan teman di sektor pertanian dengan sikap pemuda terhadap pekerjaan di sektor pertanian.

\begin{tabular}{lcc}
\hline $\begin{array}{c}\text { Interaksi dengan Teman di Sektor Pertanian } \\
(\mathrm{X} 2)\end{array}$ & $\begin{array}{c}\text { Analisis } \\
\text { Data }\end{array}$ & $\begin{array}{c}\text { Sikap } \\
(\mathrm{Y} 1)\end{array}$ \\
\hline Bekerja di Sawah Bersama Teman & $R s$ & $0.554^{\star *}$ \\
\hline Bermain di Sawah Bersama Teman & $R s$ & $0.285^{\star *}$ \\
\hline
\end{tabular}

Walgito (2010) mengatakan bahwa tingkat kedekatan dengan teman (closeness) dapat menggambarkan tingkah laku yang hampir sama dan memiliki perasaan yang sama terhadap suatu obyek. Sehingga dapat dijelaskan bahwa pemuda yang memiliki teman baik yang bekerja di bidang pertanian akan memberikan dampak atau pengaruh pada pandangan pemuda tersebut dalam melihat pertanian. Biasanya terdapat pemuda yang diajak temannya untuk sekedar membantu di kebun dan membicarakan informasi-informasi tentang pertanian. Selain itu, (Nugraha \& Nugroho, 2019) juga menyatakan bahwa pada umumnya pemuda yang teman- teman dekatnya tidak bekerja di bidang pertanian seperti pedagang, tukang ojek, ataupun pelajar memiliki kecenderungan tidak bersikap positif terhadap pekerjaan di bidang pertanian. Karena dalam hubungannya mereka jarang membicarakan mengenai pertanian, hal-hal yang dibicarakan antara pemuda yang memiliki teman dekat di luar pertanian adalah masalah-masalah non-pertanian. Teman dapat menjadi agen sosialisasi yang efektif karena teman (peers) pola sosialisasinya lebih bersifat ekuilitas di mana kedudukannya setara atau sederajat. Kelompok acuan (group reference) memiliki peranan penting dalam membentuk nilai terhadap suatu pekerjaan dimata pemuda. Setiap tingkatan usia memiliki aktor - aktor utama yang mampu mempengaruhi seseorang. Pada dasarnya terdapat tiga aktor utama yang mampu mempengaruhi karakter seseorang pemuda, antara lain adalah orang tua, teman sepermainan, dan media massa. Bahkan pada fase usia tertentu sering kali terjadi pertentangan nilai-nilai antar ketiga aktor (Walgito, 2010).

\section{KESIMPULAN}

Pemuda Desa Ciasmara memiliki tingkat interaksi yang rendah dalam hal bekerja bersama teman di sawah hal ini disebabkan pemuda di desa itu tingkat interaksi yang cukup tinggi dalam hal bermain bersama teman di sawah terutama saat panen ketika sawah sudah dapat dilewati oleh anak - anak untuk bermain layangan dan bermain bola. Sikap pemuda Desa Ciasmara terhadap pekerjaan di sektor pertanian padi memiliki beberapa indikator penilaian, untuk aspek pengetahuan (kognisi) 
terhadap teknis pekerjaan di bidang pertanian terkategorikan baik, hal ini karena pemuda Desa Ciasmara masih suka melihat orang tua mereka dan dilibatkan oleh orang tua mereka dalam beberapa tahap kegiatan pertanian. Sementara itu untuk aspek afeksi terkategorikan cukup baik, hal ini karena mayoritas penduduk Desa Ciasmara bekerja sebagai petani dan Desa Ciasmara merupakan salah satu lumbung padi Kabupaten Bogor. Sementara itu aspek psikomotorik pemuda terkategorikan kurang tertarik untuk bekerja di sektor pertanian padi. Interaksi dengan teman sepermainan di bidang pertanian memliki hubungan kuat, sangat nyata, dan positif dengan sikap pemuda terhadap pekerjaan di sektor pertanian padi. Hal ini terjadi karena peer-group memegang peranan penting dalam membentuk citra tentang sebuah pekerjaan. Posisi interaksi dengan teman sepermainan sering kali dilupakan dalam memahami preferensi bekerja seorang pemuda, studi ini menemukan bahwa pemuda desa yang sering terlibat bersama temannya di sawah memiliki preferensi yang baik terhadap pekerjaan di sektor pertanian. Studi mengenai preferensi pemuda terhadap pekerjaan di sektor pertanian sudah banyak dikaji, namun hanya sedikit yang membahasnya dari perspektif agricultural peer-group proximity.

Secara teoritik, perlu perspektif yang luas dalam memahami rendahnya ketertarikan pemuda untuk bekerja di sektor pertanian. Keputusan pemuda tidak tertarik atau tidak mau bekerja di sektor pertanian bukan keputusan satu kali dalam seumur hidup. Keputusan tersebut sangat dinamis dan dapat berubah oleh karena itu sangat dibutuhkan studi lanjutan mengenai Farmer Life Cycle agar dapat mengidentifikasi mengenai pola hidup petani dari muda sampai tua agar dapat diketahui mengenai pola kehidupan petani, karena sebagian besar petani di Indonesia sekarang pernah melakukan migrasi ketika muda dan sampai titik tertentu mereka kembali lagi ke desa. Dinas pendidikan Kabupaten Bogor perlu memikirkan ulang mengenai mata pelajaran muatan lokal yang perlu disajikan di wilayah - wilayah sentra pertanian. Muatan lokal yang berkaitan dengan pertanian peting untuk dimunculkan untuk tingkat SD - SLTA. Penelitian ini menemukan bahwa keterlibatan dalam pertanian bersama teman menjadi salah satu faktor penting dalam membentuk sikap positif pemuda terhadap pekerjaan di sektor pertanian.

\section{UCAPAN TERIMA KASIH}

Penulis mengucapkan terima kasih kepada Dirjen Penguatan Riset dan Pengembangan Kementerian Riset, Teknologi, dan Pendidikan Tinggi yang telah memberikan bantuan dana hibah penelitian sampai penelitian ini terlaksana. Ucapan terima kasih juga disampaikan kepada pihakpihak lain yang terkait atas bantuan yang diberikan kepada penulis.

\section{REFERENSI}

Ashari, Sharifuddin, J., Mohammed, Z. A., \& Rika, T. (2016). Persepsi dan Sikap Petani Padi terhadap Niat untuk Mengadopsi. Jurnal Agro Ekonomi, 34(1), 35-46.

Badan Pusat Statistik. (2017). Indikator Ekonomi. In Buletin Statistik Bulanan (Issue November). https://doi.org/10.11607/ijp.3688

Harahap, R. A., \& Ambarwati, A. (2015). Tanah Untuk Penggarap? Penguasaan Tanah dan Struktur Agraris di Beberapa Desa Penghasil Padi. Jurnal Analisis Sosial Akatiga, 19(1), 1-30.

Jayawinangun, R., \& Nugraha, Y. A. (2018). Penggunaan Internet Dan Media Sosial Orang Muda Di Pedesaan. Wahana, 24(2), 1-14.

Neuman, W. L. (2014). Social Research Methods: Qualitative and Quantitative Approaches. In Teaching Sociology (Vol. 30, Issue 3). https://doi.org/10.2307/3211488

Nugraha, YA. (2012). Hubungan Orang Tua, Teman, dan Media Massa dengan Sikap Pemuda terhadap Pekerjaan di Bidang Pertanian Kasus Desa Cipendawa dan Sukatani, Kecamatan Pacet, Kabupaten Cianjur [Tesis]. Bogor (ID): Institut Pertanian Bogor.

Nugraha, Y. A., \& Herawati, R. (2015). Menguak realitas orang muda sektor pertanian di perdesaan. Seri Penelitian Akatiga, 19(1).

Nugraha, Y. A., \& Nugroho, D. R. (2019). Rural Youth Behavior In Watching Television (Case Study Rural Youth in Ciasmara Village Pamijahan Sub-District, Bogor Regency). Jhss (Journal of Humanities and Social Studies), 3(1), 32-36. https://doi.org/10.33751/jhss.v3i1.1098

Valdiani, D., Nugraha, Y. A., \& Siregar, M. R. . (2017). Attendance Of Mass Media And Parents In Defining The Value Of Agriculture In The Eyes Of Rural (Case Study of Rural Youth at Horticulture Center in Cianjur Regency). Jhss (Journal of Humanities and Social Studies), 1(1), 28-34. https://doi.org/10.33751/jhss.v1i1.370

Walgito, B. 2010. Psikologi Sosial. Yogyakarta (ID): CV. Andi Offset. 
White, B. (2018). Marx and Chayanov at the margins: understanding agrarian change in Java. The Journal of Peasant Studies, 45(5-6), 1108-1126. https://doi.org/10.1080/03066150.2017.1419191 